\title{
A new purported ankylosaur trackway in the Lower Cretaceous (lower Aptian) shallow-marine carbonate deposits of Puglia, southern Italy
}

\author{
Fabio Massimo Petti ${ }^{\mathrm{a}, \mathrm{b}, *}$, Simone D’Orazi Porchetti $^{\mathrm{b}}$, Eva Sacchi ${ }^{\mathrm{b}}$, Umberto Nicosia ${ }^{\mathrm{b}}$ \\ ${ }^{a}$ Museo Tridentino di Scienze Naturali, Via Calepina, 14-38122 Trento, Italy \\ ${ }^{\mathrm{b}}$ Dipartimento di Scienze della Terra, Sapienza Università di Roma, P.le Aldo Moro, 5-00185 Rome, Italy
}

\section{A R T I C L E I N F O}

\section{Article history:}

Received 22 December 2009

Accepted in revised form 23 July 2010

Available online 29 July 2010

\section{Keywords:}

Dinosaur footprints

Apulian Platform

Early Cretaceous

Thyreophora

Ankylosauria

southern Italy

\begin{abstract}
A B S T R A C T
The Apulian marine carbonate Platform, an unusual environment for terrestrial animals, has revealed a diverse ichnological record, especially for dinosaurs. Members of most higher taxa are present, including sauropods, theropods, ankylosaurs and ornithopods. Recently, a small outcrop of Aptian age referred to the Calcare di Bari near Bisceglie (Bari) has yielded a new quadrupedal trackway that we attribute to Ankylosauria. This new find enhances the record of Cretaceous ankylosaur footprints from the Apulian carbonate Platform, previously known from another site near Bisceglie (early Aptian), from Borgo Celano (late Hauterivian-early Barremian), and from Altamura (late Coniacian-early Santonian).
\end{abstract} (c) 2010 Elsevier Ltd. All rights reserved.

\section{Introduction}

In addition to the Bisceglie track site reported here dinosaur track sites are well documented in the Lower Cretaceous of the Murge area and the Gargano Promontory in Puglia (Petti et al., 2008; Sacchi et al., 2009). Five Cretaceous dinosaur track sites have been discovered so far on the Apulian carbonate Platform (Nicosia et al., 2000a,b; Conti et al., 2005; Petti et al., 2008, 2009; Sacchi et al., 2009), most of which are associated with the Lower Cretaceous deposits of the Calcare di Bari Fm. A diverse ichnocoenosis is recorded here: it includes sauropods, theropods, ornithopods and ankylosaurs.

Even if the Gargano Promontory footprints (Borgo Celano ichnosite; Petti et al., 2008) are ascribed to the late Hauterivian-early Barremian deposits of the San Giovanni Rotondo Fm, as recent stratigraphic studies suggest (Spalluto and Pieri, 2008), the latter formation is considered a synonym of the Calcare di Bari Formation, and the type area and type locality of the latter are on the Murge Plateau. The occurrence of dinosaur footprints on the Apulian carbonate Platform has lead us to re-examine the sedimentary evolution of this domain; in turn, this has provided important palaeontological constraints on how Cretaceous Western Tethyan palaeogeography can be interpreted (Sacchi et al., 2009).

\footnotetext{
* Corresponding author. Museo Tridentino di Scienze Naturali, Via Calepina, 14-38122 Trento, Italy.

E-mail address: fabio.petti@mtsn.tn.it (F.M. Petti).
}

This paper focuses on a new quadrupedal trackway produced by an ankylosaur, discovered at a site near Bisceglie (Bari, southern Italy) (Fig. 1). Footprints inferred to have been produced by ankylosaurs have previously been reported from the Lower Cretaceous carbonate deposits of the Gargano Promontory (Petti et al., 2008) and from a quarry near the town of Bisceglie (Sacchi et al., 2009), while isolated Upper Cretaceous ankylosaur tracks are known from Altamura (Dal Sasso, 2003; Petti, 2006) (see Fig. 2).

This study deals with a moderately well-preserved ankylosaur trackway from the Puglia region, made up of a sequence of nine consecutive manus-pes sets.

\section{Stratigraphical and sedimentological setting}

The Murge Plateau and the Gargano Promontory represent the Apulian foreland of the Apenninic orogenic system, developed since the Neogene as a consequence of the high subsidence rates related to the eastward rollback of the hinge of the west-dipping Apenninic subduction (Ricchetti et al., 1992; Doglioni et al., 1996). The Calcare di Bari Fm crops out extensively in the Murge area trending northwest-southeast, from Andria to the north down to Fasano to the south (Ciaranfi et al., 1992). It forms a thick pile of sediments (at least $2000 \mathrm{~m}$ ) deposited on the Apulian carbonate Platform during the ?Callovian-Coniacian (for a review of the unit see also Delfrati et al., 2003 and Spalluto and Pieri, 2008). The unit has been analyzed in detail for stratigraphical purposes, and different informal lithostratigraphic subdivisions have been 


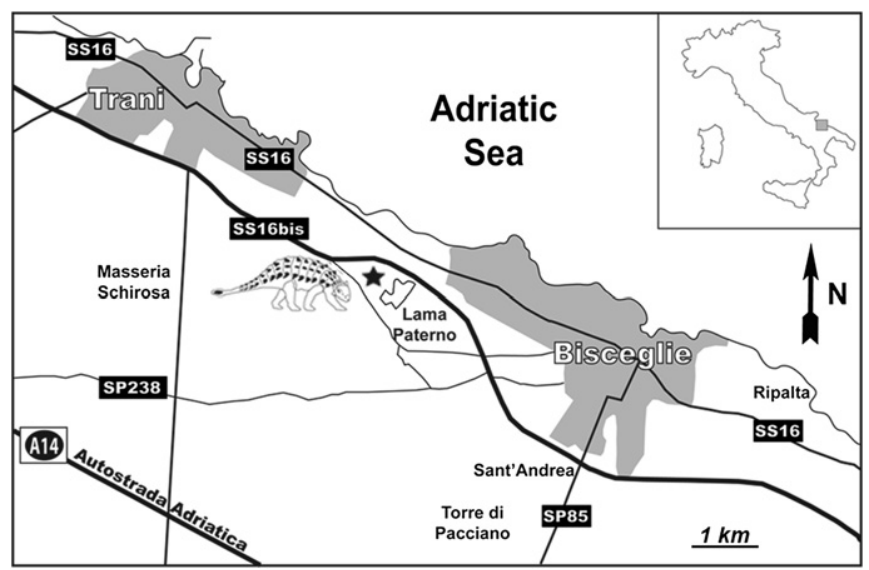

Fig. 1. Locality map showing the new dinosaur trackway near the town of Bisceglie. The star indicates the exact position of the outcrop.

proposed (Valduga, 1965; Ricchetti, 1969; Campobasso et al., 1972; Luperto Sinni and Masse, 1982, 1984, 1986, 1993; Luperto Sinni and Borgomano, 1989; Ciaranfi et al., 1992; Spalluto and Pieri, 2008).

The new ichnosite is located close to the town of Bisceglie (Bari, southern Italy), about $1 \mathrm{~km}$ northwest of the Lama Paterno quarry, where Sacchi et al. (2009) discovered and described an early Aptian dinosaur ichnocoenosis. The track-bearing layer crops out between Via Crosta and the SS16 BIS national highway (Fig. 1; GPS coord. Lat. $41,2522 \mathrm{~N}$; Long. 16,4500 E), on an NNE dipping (about $10^{\circ}$ ) surface ascribed to the middle portion of the Calcare di Bari Fm (Luperto

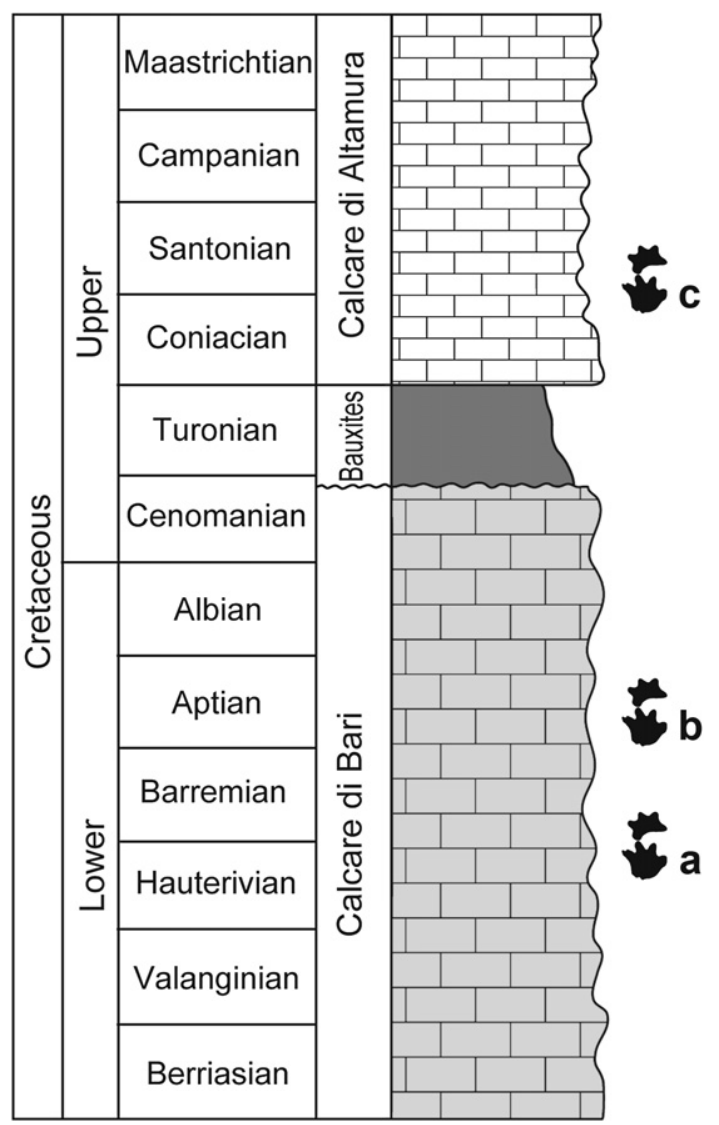

Fig. 2. Stratigraphic distribution of purported ankylosaur tracks in the Cretaceous platform deposits of Murge and Gargano Promontory (Puglia, southern Italy). (a) Borgo Celano; (b) Bisceglie; (c) Altamura. After Dal Sasso (2003), Petti et al. (2008) and Sacchi et al. (2009)
Sinni and Masse, 1993). The track-bearing level is $76 \mathrm{~cm}$ thick exposed over no more than $20 \mathrm{~m}^{2}$. From the base to the top we recognized a basal portion characterized by a mudstone-wackestone with miliolids passing upward to a bioclastic wackestone with bivalve shell fragments, topped by a grainstone with fenestral fabrics. This coarsening-upward succession indicates a shallowing-upward cycle as confirmed by tracks occurrence.

Micropaleontological analysis revealed the occurrence of Hensonella dinarica (Radoičić, 1959), Praechrysalidina infracretacea Luperto Sinni 1979 and Debarina hahounerensis Fourcade et al., 1972, an assemblage referable to the Salpingoporella dinarica Zone (sensu Chiocchini et al., 2008) that constrains the age of the trackbearing bed to the early Aptian. The lithofacies and the micropaleontological assemblage clearly indicate an inner carbonate platform-back edge palaeoenvironment.

\section{Material and methods}

The material was photographed and traced on transparent acetate overlays but no molding of the surface has been performed. Unexpectedly, the trackway, found in a test quarry area, is no longer exposed, since a thick cover of filling material buried the site. In this paper we adopted the prefix BiC (Bisceglie, Via Crosta) to describe the trackway and single manus-pes couples.

The trackway is $5.40 \mathrm{~m}$ long and on average $60 \mathrm{~cm}$ wide (Fig. 3). It consists of nine manus-pes couples with a regular heteropody index (about $1 / 2$ ). Pes pace angulation varies slightly from $115^{\circ}$ to $131^{\circ}$, but a range of manus pace angulations between $131^{\circ}$ and $147^{\circ}$. Manus-pes distance ranges from 6 to $16 \mathrm{~cm}$. The trackway is straight and narrow gauge for all its length, and represent a true tracking surface, as testified by displacement bulges surrounding several tracks (Fig. 4).



Fig. 3. Photograph of the $\mathrm{BiC}$ ankylosaur trackway. Hammer $(33 \mathrm{~cm})$ for scale. 


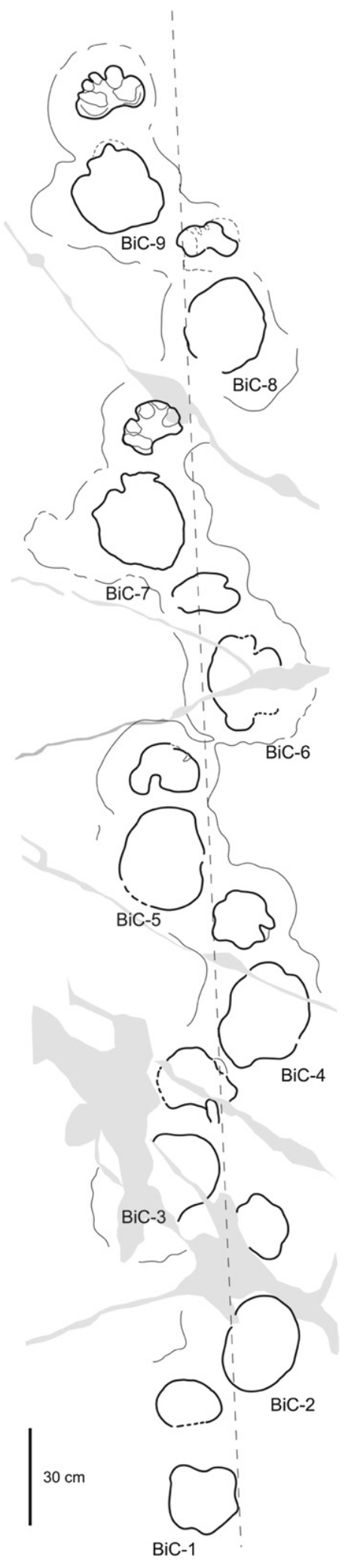

Fig. 4. Tracing of the BiC trackway sequence. Rock fractures are marked in pale grey.

The pedal imprints are roughly longer than wide. They are on average about $30 \mathrm{~cm}$ long while width varies from a minimum of $23 \mathrm{~cm}$ to a maximum of $29 \mathrm{~cm}$. Pedal prints are oriented in the direction of travel, nonetheless in BiC-4, BiC-6, BiC-7 and BiC-9 the pes morphology tapers proximally, close to the midline, suggesting a low outward rotation of the pes with respect to the midline $\left(25^{\circ}-39^{\circ}\right)$. The trampled coarse-grained sediments affected the actual morphology of pedal prints, hiding the fine anatomy of the trackmaker's pes. The recent subaerial exposure and consequent weathering effects have contributed to worsen preservation. However in BiC-7 and BiC-9 three to four short and rounded lobes occur distally, here interpreted as digit traces.

Manus impressions always lie close to the midline, sometimes crossing it (BiC-3 and $\mathrm{BiC}-6$ ). Manus prints are always wider than long and are smaller than pes traces. Manus morphology varies from sub-circular to crescentic with a concave indentation in the middle of the rear margin, as evidenced in BiC-5, BiC-8 and BiC-9. In BiC-8 and particularly in BiC-9 there are five rounded digit impressions. The inferred manus digit prints are arranged as follows: digits I and V are rounded and are similar in size while digits II-IV are short and stubby. Manual prints are more shallowly impressed posteriorly. The actual dimensions of the manus are easier to define in $\mathrm{BiC}-8$, and the shallow area behind digits I and $\mathrm{V}$ in BiC-9 (Fig. 5) could be interpreted as the effect of faint sliding traces. The axes of digits II, III, and IV point slightly outward.

Pace and stride length and other morphometrical parameters are reported in Table 1.

The distance between the shoulder joint and the hip joint (GAD = gleno-acetabular distance), measured following the methodology of Leonardi (1987) is $85 \mathrm{~cm}$, with an estimated body
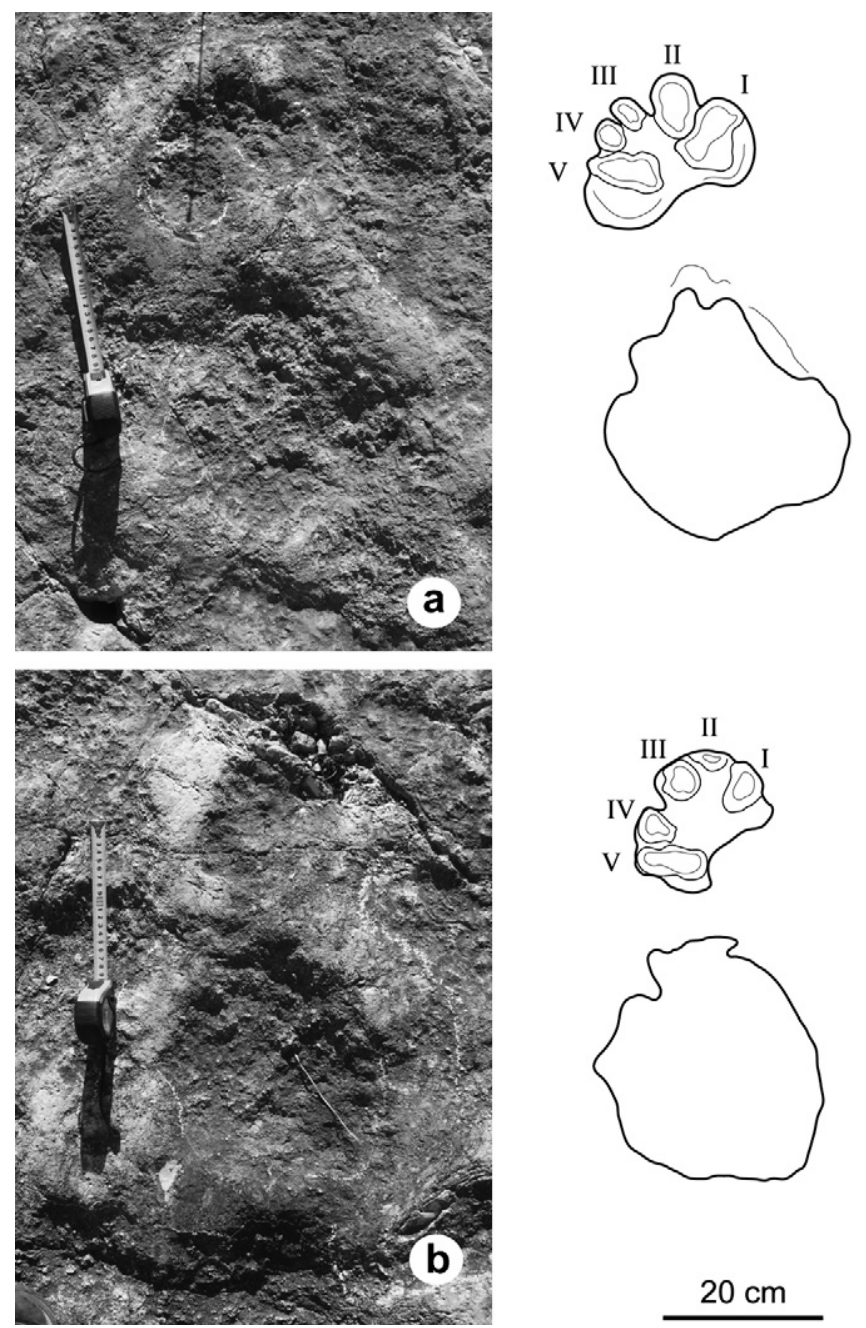

Fig. 5. Photographs and interpretive drawings of the best-preserved manus-pes sets (a: BiC-7 and b: BiC-9). 
Table 1

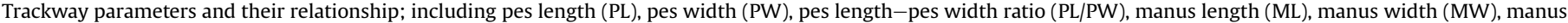

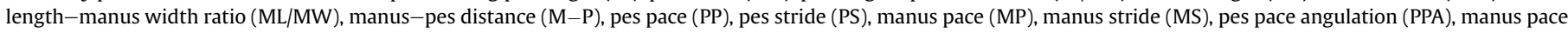
angulation (MPA). All the measurements are expressed in $\mathrm{cm}$ and degrees.

\begin{tabular}{|c|c|c|c|c|c|c|c|c|c|c|c|c|c|}
\hline Track & PL & PW & PL/PW & ML & MW & ML/MW & $\mathrm{M}-\mathrm{P}$ & PP & PS & MP & MS & PPA & MPA \\
\hline BiC-1 & 24 & 23 & 1.04 & 15 & 21 & 0.71 & 16 & 51 & 101 & 60 & 100 & $131^{\circ}$ & $132^{\circ}$ \\
\hline $\mathrm{BiC}-2$ & 30 & 24 & 1.25 & 20 & 16 & 1.25 & 11 & 61 & 101 & 50 & 95 & $121^{\circ}$ & $138^{\circ}$ \\
\hline $\mathrm{BiC}-3$ & 27 & 23 & 1.17 & 18 & 27 & 0.67 & 10 & 55 & 97 & 51 & 98 & $115^{\circ}$ & $136^{\circ}$ \\
\hline $\mathrm{BiC}-4$ & 36 & 29 & 1.24 & 20 & 21 & 0.95 & 7 & 60 & 105 & 55 & 102 & $120^{\circ}$ & $139^{\circ}$ \\
\hline $\mathrm{BiC}-5$ & 33 & 29 & 1.14 & 17 & 22 & 0.77 & 5 & 61 & 104 & 60 & 105 & $121^{\circ}$ & $147^{\circ}$ \\
\hline $\mathrm{BiC}-6$ & 31 & 25 & 1.24 & 15 & 22 & 0.68 & 7 & 55 & 110 & 57 & 110 & $122^{\circ}$ & $145^{\circ}$ \\
\hline $\mathrm{BiC}-7$ & 31 & 27 & 1.15 & 17 & 18 & 0.94 & 5 & 63 & 104 & 60 & 104 & $118^{\circ}$ & $131^{\circ}$ \\
\hline $\mathrm{BiC}-8$ & 30 & 26 & 1.15 & 12 & 19 & 0.63 & 7 & 56 & & 55 & & & \\
\hline BiC-9 & 29 & 28 & 1.03 & 18 & 22 & 0.81 & 12 & & & & & & \\
\hline
\end{tabular}

length of about $2.4 \mathrm{~m}$. The gauge is narrow, and the trackmaker was a quadruped with a hip height of about $120 \mathrm{~cm}$ (Alexander, 1976). It seems to have been walking at an average speed of $3.10 \mathrm{~km} / \mathrm{h}$ (following the equation in Thulborn, 1990).

\section{Discussion}

Fossil footprints preserved in the Apulian platform deposits are often poor in fine anatomical detail (Nicosia et al., 2000a, b; Conti et al., 2005; Petti et al., 2008; Sacchi et al., 2009) and the BiC material is also suboptimal. With the BiC trackway it is possible to identify a potential trackmaker to a high taxonomic rank. However, the preservation prevents ichnotaxonomic assignment of the specimen.

The trackmaker identification process is here based on the comparison of soft part traces with body fossil morphology. The tracks are complete enough to preserve important features of the autopodia.

Quadrupedalism was widely adopted by Cretaceous dinosaurs and - except for theropods and small ornithopods - all other groups shared this gait.

The forelimb traces of Cretaceous ornithopods are quite homogeneous and are usually no more than one-third the dimension of the foot (Thulborn, 1990). This ratio is smaller than BiC manual/pedal print ratios and therefore the group is excluded from potential trackmakers. Moreover the tridactyl pes is unlikely to have left a rounded print as found in the BiC trackway.

Quadrupedalism was obligatory for sauropods, and their foreand hind-limbs have been extensively investigated as have their tracks (see Lockley et al., 1994; Wilson and Carrano, 1999). Remarkably, this group reached the largest dimensions ever seen in terrestrial animals: footprints which are larger than $1 \mathrm{~m}$ in length are exclusively referred to Sauropoda (Thulborn et al., 1994; Lockley et al., 2007). On the other hand smaller or dwarf forms (Sander et al., 2006) could have left footprints similar in gross shape and dimensions to the BiC tracks. Nevertheless features evident in the $\mathrm{BiC}$ trackway are inconsistent with known sauropod ichnogenera. Although the gauge could be attributed to a sauropod, the heteropody index and the pace angulation do not match with purported narrow-gauge sauropod trackways (Parabrontopodus isp., Lockley et al., 1994). Moreover, the BiC manual prints are always significantly different from the sauropod manual ichnites (Dutuit and Ouazzou, 1980; Farlow et al., 1989; Lockley et al., 1994, 2002; Santos et al., 2009) and particularly from those found in the Lower Cretaceous deposits of northern Italy (Dalla Vecchia, 1999) and Croatia (Dalla Vecchia and Tarlao, 2000). Sauropod manual prints are often wider than long but they display remarkably different characters such as the position and morphology of digit traces. All evidence, including ichnites and body fossils (Lockley et al., 1994; Apesteguía, 2005) shows that the manus of Cretaceous sauropods was embedded in a single pad, with no free digits, although in some cases a huge claw trace of digit I stands out as a remarkable feature (Santos et al., 2009). No evidence of this structure has been found in the Apulian trackway. Furthermore during the Aptian sauropods were essentially represented by macronarians (e.g. brachiosaurs and titanosaurs; Wilson and Sereno, 1998), showing little dimensional differences between the fore- and hind-limbs (Apesteguía, 2005). These differences are apparently reflected in tracks and trackways (Lockley et al., 1994) and macronarians seem to be more consistent with the largemanus and wide-gauge Brontopodus-like tracks common in the Lower Cretaceous deposits, and reported also from the Upper Cretaceous (Farlow, 1992; Lockley et al., 1994, 2002; Wilson and Carrano, 1999). Additionally, basal titanosauriform macronarians display lengthened metacarpals and extremely reduced phalanges, while in titanosaurs the long metacarpals were arranged vertically with the complete loss of all phalanges (Apesteguía, 2005). Consequently, manual digit traces should be absent in the latter group and the occurrence of digit marks in the best preserved manual prints of Bisceglie (BiC-8 and BiC-9) would seem to exclude titanosaurs as potential trackmakers.

Members of Marginocephalia and Thyreophora show comparatively homogeneous patterns in manual shape and arrangement. Five digits, with short and blunt claws and shortened phalanges, are common to stegosaurs, ceratopsians and ankylosaurs (Vickarous et al., 2004; Galton and Upchurch, 2004; Hailu and Dodson, 2004; Dodson et al., 2004). In contrast, pes morphology differs slightly among these groups.

Ceratopsians (basal Ceratopsia and Ceratopsidae) display a tetradactyl pes with four functional metatarsals (I-IV) (Hailu and Dodson, 2004; Dodson et al., 2004). Ceratopsians and their purported tracks are worth comparing to the Apulian material. The only purported ceratopsian ichnospecies, Ceratopsipes goldenensis Lockley and Hunt, 1995a, from the Maastrichtian of Colorado (Lockley and Hunt, 1995a), has a wider trackway gauge and its manus prints are clearly placed outward in relation to the position of the pes prints of the BiC trackway. The pes is also different from C. goldenensis, being as wide as long. Furthermore ceratopsian skeletal remains are mainly confined to the Upper Cretaceous deposits of United States and Canada, even if non-horned Asian ceratopsians were found in slightly earlier Cretaceous deposits (Dodson et al., 2004). To date no record of ceratopsians is known from northern Africa and only very recently few European ceratopsians - with Asian affinities - have been discovered (Ösi et al., 2010). Additionally some early representatives of ceratopsians, such as Psittacosaurus, were probably obligate bipeds (Hailu and Dodson, 2004; Senter, 2007).

Stegosaurs had essentially tridactyl pedes (Galton and Upchurch, 2004), even if some exceptions are recorded in Late Jurassic specimens (Tuojiangosaurus; Dong et al., 1977) which show four digits in the pes. Tracks probably attributed to stegosaurs were identified in various Middle-Upper Jurassic outcrops of England, Spain, Portugal and North America (Whyte et al., 2007; Lires et al., 
2002; García-Ramos et al., 2008; Lockley et al., 2008; Mateus and Milàn, 2008, 2010; Milàn and Chiappe, 2009). Footprints named as Deltapodus brodricki Whyte and Romano 1994 seem to show the best fit for stegosaur pes anatomy (Whyte and Romano, 2001). This ichnospecies is characterized by crescent-shaped manus impression (wider than long), and by a triangular to subtriangular tridactyl pes (Whyte and Romano, 1994). It is therefore unlikely that the tracks described here can be attributed to stegosaurian dinosaurs.

Ankylosaur pedes are variable, being either pentadactyl (Sauropelta), tetradactyl (Talarurus) or tridactyl (Euoplocephalus) (Vickarous et al., 2004). The manus is usually pentadactyl slightly smaller than the pes and its stubby digits are arranged in a semicircular or radiating pattern (Thulborn, 1990). Late Cretaceous ankylosaur trackways show several similarities with our new finding, such as the heteropody, the gauge, and the overall dimensions. Potential ankylosaur tracks and trackways are known from more than a dozen of localities in Europe, North America, South America and Asia (Sternberg, 1932; Zakharov, 1964; Haubold, 1971; Lockley and Hunt, 1995b; Gangloff, 1998; Lockley et al., 1999, 2006; Lockley and Meyer, 2000; McCrea and Currie, 1998; McCrea and Sarjeant, 1999; McCrea, 2000; Meyer et al., 2001; Petti, 2006; Stanford et al., 2007; Petti et al., 2008; McCrea and Buckley, 2008; Sacchi et al., 2009; see also Thulborn, 1990 and McCrea et al., 2001 for a review of purported ankylosaur tracks). Probably only two out of five ichnospecies listed by McCrea et al. (2001) can be confidently attributed to ankylosaurs, namely Tetrapodosaurus borealis (Sternberg, 1932) from the Lower Cretaceous of Canada and Metatetrapous valdensis Haubold 1971 from the Lower Cretaceous of Germany. Macropodosaurus gravis Zakharov, 1964 from the Lower Cretaceous of Central Asia, considered by some authors (McCrea et al., 2001), as an ankylosaur track was recently reinterpreted as a probable therizinosaur ichnite (Sennikov, 2006; Gierliński, 2009; Gierliński and Lockley, in review).

The Bisceglie trackway displays a step angle comparable with the value found in the ankylosaurian footprints of the Gething Formation (Grand Cache, Alberta, lower Albian; Sternberg, 1932) that is generally under $120^{\circ}$. In T. borealis, manual prints are about two thirds the length of the pes, whereas in the BiC trackway they are about half the length of the pes prints. It should be noted that the manus and pes prints of $T$. borealis have long digit traces. However, the manus morphology displays some analogies with the Apulian material; indeed the pentadactyl manus of T. borealis is characterized by a "backward" projection of digits I and V with respect to the direction of travel. The best-preserved manual prints of the new trackways (Fig. 5; BiC-8 and BiC-9) show a similar pattern although the digit traces are blunter with sub-circular traces of digits I and V, that are less obviously directed laterally and medially. The poor preservation of the pedal prints does not allow thorough comparison with North American material. The gauge of the BiC trackway fits well with both Metatetrapous valdensis Haubold 1971 from the Lower Cretaceous of Germany (Bueckburg Formation, Berriasian) and M. gravis Zakharov 1964 from the Lower Cretaceous of Tadjikistan (Shirabod Suite, Albian). The first ichnospecies differs from the Apulian material in having an apparently tridactyl manus. $M$. gravis has a similar pace angulation $\left(145^{\circ}\right)$ but it lacks manual prints, due to overprinting processes according to McCrea et al. (2001). A close match was found with the ankylosaurian manus prints from the Upper Cretaceous of Northeast British Columbia (Dunvengan Formation; Cenomanian; fig. 20.24b of McCrea et al., 2001) and Altamura (Apulia; upper Coniacian-lower Santonian; Dal Sasso, 2003; fig. 10 p. 54). Apulosauripus federicianus (Nicosia et al., 2000b), originally attributed to a medium-sized hadrosaurid, has been reinterpreted by Gierliński et al. (2005) as ankylosaurian in origin. Although some ankylosaurs may have tridactyl hands (possibly Panoplosaurus) while others may have tridactyl feet (Euoplocephalus) the combination of both characters has yet to be reported, thus excluding ankylosaurs from possible trackmakers.

The morphometric parameters measured in the BiC trackway (heteropody index and pace angulation) revealed also some affinities with the BLP4 and BLP6 quadruped trackways found in the Lama Paterno quarry (Bisceglie), and attributed respectively to an undetermined ornitischian and to a medium-sized ankylosaur (Sacchi et al., 2009). The hypothesis of ankylosaur as the most suitable trackmaker is somewhat corroborated by the manus position in the BiC trackway, often internal to the pes position and/ or crossing the midline. Indeed, functional and morphological analyses of fore- and hind-limbs have demonstrated that ankylosaurs held the humerus posteroventrally oblique with respect to the long axis of the body while the femur was erect (Maryanska, 1977; Coombs, 1978a,b, 1979). Ankylosaurs have a global distribution, their fossils occurring in Europe, Australia, South America, Antarctica, North America and Asia. This new find endorses their presence on the Apulian platform during the Early Cretaceous.

\section{Concluding remarks}

The new discovery of a dinosaur trackway in the Aptian levels of the Calcare di Bari emphasizes the importance of this formation in attempts to reconstruct the abundance and diversity of Early Cretaceous dinosaurs in the Apulian carbonate Platform. It also highlights the high density of ankylosaur tracks in southern Italy. The track-bearing level belongs to a platform sequence typical of an inner carbonate platform-back edge palaeoenvironment and was subjected to reiterated subaerial exposure. Footprint morphologies and trackway parameters suggest that the trackway can be referred to a thyreophoran, most probably an ankylosaur. This inference is consistent with the known ichnological and body fossil records. This is the fourth discovery of thyreophoran tracks in the Cretaceous of Apulia, and compels palaeontologists to understand the dispersal pattern of this globally distributed dinosaur group.

\section{Acknowledgments}

The authors are grateful to A. Logoluso, who discovered the trackway, for his valuable help during the field work. We wish to thank also M. Bernardi (Museo Tridentino di Scienze Naturali) for his helpful advices on the manuscript. We thank M.G. Lockley and R.T. McCrea who provided helpful reviews and D. Naish that greatly improved the final version of the manuscript.

This research was supported by the DINOGEO post-doc Project (Servizio Università e Ricerca scientifica, Fondo Unico per i progetti di ricerca della Provincia Autonoma di Trento, L.P. n.3, 20.03.2000).

\section{References}

Alexander, R.McN., 1976. Estimates of speed of dinosaurs. Nature 261, 129-130. Apesteguía, S., 2005. Evolution of the titanosaur metacarpus. In: Tidwell, V. Carpenter, K. (Eds.), Thunder-Lizards, The Sauropodomorph Dinosaurs. Indiana University Press, Bloomington, pp. 321-345.

Campobasso, V., Ricchetti, G., Luperto Sinni, E., 1972. Note stratigrafiche e paleontologiche sugli strati più profondi del Calcare di Bari nelle Murge baresi. Bollettino della Società Geologica Italiana 91, 47-85.

Chiocchini, M., Chiocchini, R.A., Didaskalou, P., Potetti, M., 2008. Upper Triassic Jurassic and Cretaceous microbiostratigraphy of the carbonatic platform facies in the central-southern Latium and Abruzzi. In: Chiocchini, M. (Ed.), Micropaleontological and Biostratigraphical Researches on the Mesozoic of the LatiumAbruzzi Carbonate Platform (Central Italy). Memorie Descrittive della Carta Geologica d'Italia, vol. 84, pp. 1-169.

Ciaranfi, N., Pieri, P., Ricchetti, G., 1992. Note alla carta geologica delle Murge e de Salento (Puglia centro-meridionale). Memorie della Società Geologica Italiana 41 (1988), 449-460.

Conti, M.A., Morsilli, M., Nicosia, U., Sacchi, E., Savino, V., Wagensommer, A., Di Maggio, L., Gianolla, P., 2005. Jurassic dinosaur footprints from southern 
Italy: footprints as indicators of constraints in paleogeographic interpretation. Palaios 20 (6), 534-550.

Coombs Jr., W.P., 1978a. The families of the ornithischian dinosaur Order Ankylosauria. Palaeontology 21, 143-170.

Coombs Jr., W.P., 1978b. Forelimb muscles of the Ankylosauria (Reptilia, Ornithischia). Journal of Paleontology 52, 642-658.

Coombs Jr., W.P., 1979. Osteology and myology of the hindlimb in the Ankylosauria (Reptilia, Ornithischia). Journal of Paleontology 53, 666-684.

Dalla Vecchia, F.M., 1999. A sauropod footprint in a limestone block from the Lower Cretaceous of northeastern Italy. Ichnos 6, 269-275.

Dalla Vecchia, F.M., Tarlao, A., 2000. New dinosaur tracksites in the Albian (Early Cretaceous) of the Istrian peninsula (Croatia). Parte II-Paleontology. Memorie di Scienze Geologiche 52, 227-292.

Dal Sasso, C., 2003. Dinosaurs of Italy. Comptes Rendus Palevol 2, 45-66.

Delfrati, L., Falorni, P., Izzo, P., Petti, F.M., 2003. Carta Geologica d'Italia alla scala 1:50.000, Catalogo delle Formazioni, Unità validate. Quaderni serie III 7 (5), pp. 210. APAT, Dipartimento Difesa del suolo, Roma.

Dodson, P., Forster, C.A., Sampson, S.D., 2004. Ceratopsidae. In: Weishampel, D.B., Dodson, P., Osmólska, H. (Eds.), The Dinosauria, second edition. University of California Press, London, pp. 494-513.

Doglioni, C., Tropeano, M., Mongelli, F., Pieri, P., 1996. Middle-Late Pleistocene uplift of Puglia: an "anomaly" in the Apenninic foreland. Memorie della Società Geologica Italiana 51, 101-117.

Dong, Z., Li, X., Zhou, S.W., 1977. On the stegosaurian remains from Zigong (Tzekung), Szechuan Province. Vertebrata Palasiatica 15, 307-312 (in Chinese with English summary).

Dutuit, J.M., Ouazzou, A., 1980. Découverte d'une piste de dinosaur sauropode sur le site d'empreintes de Demnat (Haut-Atlas Marocain). Mémoire de la Société Géologique de France, Nouvelle Série 139, 95-102.

Farlow, J.O., 1992. Sauropod tracks and trackmakers: integrating the ichnological and skeletal records. Zubia 10, 89-138.

Farlow, J.O., Pittman, J.G., Hawthorne, J.M., 1989. Brontopodus birdi, Lower Cretaceous sauropod footprints from the U.S. Gulf coastal plain. In: Gillette, D.D. Lockley, M.G. (Eds.), Dinosaur Tracks and Traces. Cambridge University Press, Cambridge, pp. 371-394.

Fourcade, E., Raoult, J.F., Vila, J.M., 1972. Debarina hahounerensis n. gen., n. sp. nouveau lituolidé (Foraminifère) du Crétacé inférieur constantinois. Comptes Rendus de l'Académie des Sciences de Paris 274, 191-193.

Galton, P.M., Upchurch, P., 2004. Stegosauria. In: Weishampel, D.B., Dodson, P., Osmolska, H. (Eds.), The Dinosauria, second edition. University of California Press, London, pp. 343-362.

Gangloff, R.A., 1998. Arctic dinosaurs with emphasis on the Cretaceous record of Alaska and the Eurasian-North American connection. In: Lucas, S.G., Kirkland, J.I., Estep, J.W. (Eds.), Lower and Middle Cretaceous Terrestrial Ecosystems. New Mexico Museum Natural History and Science Bulletin, vol. 14 pp. $211-220$.

García-Ramos, J.C., Piñuela, L., Ruiz-Omeñaca, J.I., Pereda-Suberbiola, X., 2008. Costas Jurásicas frecuentas por estegosaurios. In: Ruiz-Omeñaca, J.I., Piñuela, L. García-Ramos, J.C. (Eds.), Libro de Resúmes de las XXIV Jornadas de la Sociedad Española de Paleontología, Colunga, Astúrias, pp. 33-34.

Gierliński, G., 2009. Preliminary report on new dinosaur tracksites in the Triassic Jurassic and Cretaceous of Poland. In: Actas de Las IV Jornadas Internacionales sobre Paleontologia de Dinosaurios y su Entorno. Salas de los Infantes, Burgos, Spain, pp. 75-90.

Gierliński, G., Lockley M.G., in review. First report of probable therizinosaur (cf. Macropodosaurus) tracks from North America, with notes on the neglected vertebrate ichnofauna of the Ferron Sandstone. In Titus, A. (Ed.) Western Interior Late Cretaceous Paleontology and Geology.

Gierliński, G., Mossbrucker, M.T., Sabath, K., 2005. Stegosaurian footprints from the Morrison Formation of western United States and their implications for other finds. In: International Symposium on Dinosaurs and Other Vertebrates Palaeoichnology, Fumanya/Sant Corneli 4-8 October 2005. (Abstracts book, 28-29).

Hailu, Y., Dodson, P., 2004. Basal Ceratopsia. In: Weishampel, D.B., Dodson, P. Osmólska, H. (Eds.), The Dinosauria, second edition. University of California Press, London, pp. 478-493.

Haubold, H., 1971. Ichnia Amphibiorum et Reptiliorum Fossilium. In: Handbuck der Paläoherpetologie, vol. 18. Fischer Verlag, Stuttgart, 124 pp.

Leonardi, G. (Ed.), 1987. Glossary and Manual of Tetrapod Footprint Palaeoichnology. Departamento Nacional da Produção Mineral, Brasília, 117 pp.

Lires, J., García-Ramos, J.C., Piñuela, L., 2002. Ichnitas de estegosaurios en los ambientes deltacios del Jurásico Superior de Astúrias. In: Pérez-Lorente (Ed.), Libro de Resúmenes del Congreso Internacional Sobre Dinosaurios y Otros Reptiles Mesozoicos de España. Universidad de La Rioja, pp. 30-31.

Lockley, M.G., Hunt, A.P., 1995a. Ceratopsid tracks and associated ichnofauna from the Laramie Formation (Upper Cretaceous: Maastrichtian) of Colorado. Journal of Vertebrate Paleontology 15 (3), 592-614.

Lockley, M.G., Hunt, A.P., 1995b. Dinosaur Tracks and Other Fossil Footprints of the Western United States. Columbia University Press, New York, 338 pp.

Lockley, M.G., Meyer, C.A., 2000. Dinosaur Tracks and Other Fossil Footprints of Europe. Cambridge University Press, Cambridge, 360 pp.

Lockley, M.G., Farlow, J.O., Meyer, C.A., 1994. Brontopodus and Parabrontopodus ichnogen. nov. and the significance of wide- and narrow-gauge sauropod trackways. Gaia 10, 135-145.

Lockley, M.G., García-Ramos, J.C., Piñuela, L., Avanzini, M., 2008. A review of vertebrate track assemblages from the Late Jurassic of Asturias, Spain with comparative notes on coeval ichnofaunas from the western USA: implications for faunal diversity in association with siliciclastic facies assemblages. Oryctos $8,53-70$.

Lockley, M.G., Holbrook, J., Kukihara, R., Matsukawa, M., 2006. An ankylosaurdominated dinosaur tracksite in the Cretaceous Dakota Group of Colorado: paleoenvironmental and sequence stratigraphic context. In: Lucas, S.G. Sullivan, R.M. (Eds.), Late Cretaceous Vertebrates from the Western Interior. New Mexico Museum of Natural History and Science Bulletin, vol. 35, pp. 95-104.

Lockley, M.G., Kirkland, J.I., DeCourten, F.L., Britt, B.B., Hasiotis, S.T., 1999. Dinosaur tracks from the Cedar Mountain Formation of eastern Utah: a preliminary report. In: Gillette, D.D. (Ed.), Vertebrate Paleontology in Utah. Utah Geological Survey Miscellaneous Publication, vol. 99, pp. 253-258.

Lockley, M.G., Lires, J., García-Ramos, J.C., Pinuela, L., Avanzini, M., 2007. Shrinking the World's largest dinosaur tracks: observations on the ichnotaxonomy of Gigantosauropus asturiensis and Hispanosauropus hauboldi from the Upper Jurassic of Asturias, Spain. Ichnos 14, 247-255.

Lockley, M.G., Schulp, A.S., Meyer, C.A., Leonardi, G., Mamani, D.K., 2002. Titanosaurid trackways from the Upper Cretaceous of Bolivia: evidence for large manus, wide-gauge locomotion and gregarious behaviour. Cretaceous Research 23, 383-400.

Luperto Sinni, E., 1979. Praechrysalidina infracretacea n. gen., n. sp. (Foraminiferida) del Cretaceo inferiore delle Murge Baresi. Studi Geologici e Morfologici sulla Regione Puglia 5, 3-16.

Luperto Sinni, E., Borgomano, J., 1989. Le Crétacé supérieur des Murges sud-orientales (Italie mèridionale): stratigraphie et évolution des paléoenvironnements. Rivista Italiana di Paleontologia e Stratigrafia 95 (2), 95-136.

Luperto Sinni, E., Masse, J.P., 1982. Contributo della paleoecologia alla paleogeografia della parte meridionale della piattaforma apula nel Cretaceo inferiore. Geologica Romana 21, 859-877.

Luperto Sinni, E., Masse, J.P., 1984. Données nouvelles sur la micropaléontologie et la stratigraphie de la partie basale du "Calcare di Bari" (Crétacé inférieur) dans la région des Murges (Italie Méridionale). Rivista Italiana di Paleontologia e Stratigrafia 90 (3), 331-374.

Luperto Sinni, E., Masse, J.P., 1986. Données nouvelles sur la stratigraphie des calcaires de plate-forme du Crétacé inférieur du Gargano (Italie méridionale). Rivista Italiana di Paleontologia e Stratigrafia 92 (1), 33-66.

Luperto Sinni, E., Masse, J.P., 1993. Biostratigrafia dell'Aptiano in facies di piattaforma carbonatica delle Murge baresi (Puglia - Italia meridionale). Rivista Italiana di Paleontologia e Stratigrafia 98 (4), 403-424.

Maryanska, T., 1977. Ankylosauridae (Dinosauria) from Mongolia. Palaeontologia Polonica 37, 85-151.

Mateus, O., Milàn, J., 2008. Ichnological evidence for giant ornithopod dinosaurs in the Upper Jurassic Lourinha Formation, Portugal. Oryctos 8, 45-52.

Mateus, O., Milàn, J., 2010. A diverse Upper Jurassic dinosaur ichnofauna from central-west Portugal. Lethaia 43 (2), 245-257.

McCrea, R.T., 2000. Dinosaur footprints in the Lower Cretaceous (Albian) Gates Formation of Alberta, Canada: their use in palaeobiology and palaeoenvironmental interpretation. Journal of the Paleontological Society of Korea Special Publication 4, 169-178.

McCrea, R.T., Buckley, L.G., 2008. Fossil vertebrate tracks from the Gorman Creek Formation, northeastern B.C. In: Alberta Palaeontological Society Twelfth Annual Symposium, pp. 37-43.

McCrea, R.T., Currie, P.J., 1998. A preliminary report on dinosaur tracksites in the Lower Cretaceous (Albian) Gates Formation, near Grande Cache Alberta. In: Lucas, S.G., Kirkland, J.I., Estep, J.W. (Eds.), Lower and Middle Cretaceous Terrestrial Ecosystems. New Mexico Museum of Natural History and Science Bulletin, vol. 14, pp. 155-162.

McCrea, R.T., Sarjeant, W.A.S., 1999. A diverse vertebrate ichnofauna from the Lower Cretaceous (Albian) Gates Formation near Grand Cache, Alberta. Journal of Vertebrate Paleontology 19 (3, Suppl.), 62A.

McCrea, R.T., Lockley, M.G., Meyer, C.A., 2001. Global distribution of purported ankylosaur track occurrences. In: Carpenter, K. (Ed.), The Armored Dinosaurs. Indiana University Press, Bloomington, pp. 413-454.

Meyer, C.A., Hippler, D., Lockley, M.G., 2001. The Late Cretaceous vertebrate ichnofacies of Bolivia-facts and implications. In: Bonaparte, J.F. (Ed.), VII International Symposium on Mesozoic Terrestrial Ecosystems. Asociación Paleontológica Argentina, Publicación Especial, vol. 7, pp. 133-138.

Milàn, J., Chiappe, L.M., 2009. First American record of the Jurassic ichnospecies Deltapodus brodricki and a review of the fossil record of stegosaurian footprints. The Journal of Geology 117, 343-348.

Nicosia, U., Marino, M., Mariotti, N., Muraro, C., Panigutti, S., Petti, F.M., Sacchi, E., 2000a. The Late Cretaceous dinosaur tracksite near Altamura (Bari, southern Italy). I - Geological framework. Geologica Romana 35 (1999), 231-236.

Nicosia, U., Marino, M., Mariotti, N., Muraro, C., Panigutti, S., Petti, F.M., Sacchi, E., 2000b. The Late Cretaceous dinosaur tracksite near Altamura (Bari, southern Italy). II - Apulosauripus federicianus new ichnogen. and new ichnosp. Geologica Romana 35 (1999), 237-247.

Ősi, A., Butler, R.J., Weishampel, D.B., 2010. A Late Cretaceous ceratopsian dinosaur from Europe with Asian affinities. Nature 465, 466-468.

Petti, F.M., 2006. Orme dinosauriane nelle piattaforme carbonatiche mesozoiche italiane: sistematica e paleobiogeografia. Unpublished Ph.d Thesis, Università degli Studi di Modena e Reggio Emilia. 219 pp.

Petti, F.M., Conti, M.A., D’Orazi Porchetti, S., Morsilli, M., Nicosia, U., Gianolla, P., 2008. A theropod dominated ichnocoenosis from late Hauterivian-early 
Barremian of Borgo Celano (Gargano Promontory, Apulia, southern Italy). Rivista Italiana di Paleontologia e Stratigrafia 14 (1), 3-17.

Petti, F.M., D’Orazi Porchetti, S., Sacchi, S., Logoluso, A., Nicosia, U., 2009. A new ornithischian trackway from the Early Cretaceous of Apulia. Giornate di Paleontologia, 28-31. maggio 2009, Apricena, Abstract, 51.

Radoičić, R., 1959. Salpingoporella dinarica nov. sp. dans les sédiments Crétacés Inférieurs des Dinarides. Geolǒski Glasnik 3, 33-42.

Ricchetti, G., 1969. Calcari con Orbitoline, nuovo livello guida del Cretaceo nelle Murge baresi. Bollettino della Società Geologica Italiana 88, 321-328.

Ricchetti, G., Ciaranfi, N., Luperto Sinni, E., Mongelli, F., Pieri, P., 1992. Geodinamica ed evoluzione sedimentaria e tettonica dell'avampaese apulo. Memorie della Società Geologica Italiana 41 (1988), 57-82.

Sacchi, E., Conti, M.A., D’Orazi Porchetti, S., Logoluso, A., Nicosia, U., Perugini, G., Petti, F.M., 2009. Aptian dinosaur footprints from the Apulian platform (Bisceglie, Southern Italy) in the framework of periadriatic ichnosites. Palaeogeography, Palaeoclimatology, Palaeoecology 271, 104-116.

Sander, P.M., Mateus, O., Laven, T., Knötschke, N., 2006. Bone histology indicates insular dwarfism in a new Late Jurassic sauropod dinosaur. Nature 441 739-741.

Santos, V.F., Moratalla, J.J., Royo-Torres, R., 2009. New sauropod trackways from the Middle Jurassic of Portugal. Acta Palaeontologica Polonica 54 (3), 409-422.

Sennikov, A.G., 2006. Reading segnosaur tracks. Priroda 5, 58-67 (in Russian).

Senter, P., 2007. Analysis of forelimb function in basal ceratopsians. Journal of Zoology 273, 305-314.

Spalluto, L., Pieri, P., 2008. Geologic map of the Mesozoic-Cenozoic carbonate units cropping out in the south-western Gargano Promontory (southern Italy): new stratigraphic constraints for the tectonic evolution of the area. In: Scalise, A.R. (Ed.), Development of Geological Knowledge on the Apulian-Campanian and Tuscan-Umbrian-Marchean Apennines. Memorie Descrittive della Carta Geologica d'Italia, vol. 77, pp. 147-176.
Stanford, R., Lockley, M.G., Weems, R., 2007. Diverse dinosaur-dominated ichnofaunas from the Potomac Group (Lower Cretaceous) Maryland. Ichnos 14, 155-173.

Sternberg, C.M., 1932. Dinosaur Tracks from Peace River, British Columbia. Annual Report National Museum of Canada 1930

Thulborn, T., 1990. Dinosaur Tracks. Chapman and Hall, London, 409 pp.

Thulborn, T., Hamley, T., Foulkes, P., 1994. Preliminary report on sauropod dinosaur tracks in the Broome Sandstone (Lower Cretaceous) of Western Australia. In: Lockley, M.G., Santos dos, V.F., Meyer, C.A., Hunt, A. (Eds.), Aspects of Sauropod Paleobiology. Gaia, vol. 10, pp. 85-94.

Valduga, A., 1965. Contributo alla conoscenza geologica delle Murge baresi. In: Studi Geologici e Morfologici sulla Regione Puglia, Istituto di Geologia e Paleontologia, Università di Bari, vol. 1, 14 pp.

Vickarous, M.K., Maryańska, T., Weishampel, D.B., 2004. Ankylosauria. In: Weishampel, D.B., Dodson, P., Osmolska, H. (Eds.), The Dinosauria, second edition. University of California Press, London, pp. 363-392.

Whyte, M.A., Romano, M., 1994. Probable sauropod footprints from the Middle Jurassic of Yorkshire England. Gaia 10, 15-26.

Whyte, M.A., Romano, M., 2001. Probable stegosaurian dinosaur tracks from the Saltwick Formation (Middle Jurassic) of Yorkshire, England. Proceedings of the Geologists Association 112, 45-54.

Whyte, M.A., Romano, M., Elvidge, D.J., 2007. Reconstruction of Middle Jurassic dinosaur-dominated communities from the vertebrate ichnofauna of the Cleveland Basin of Yorkshire, UK. Ichnos 14, 117-129.

Wilson, J.A., Carrano, M.T., 1999. Titanosaurs and the origin of "wide-gauge" trackways: a biomechanical and systematic perspective on sauropod locomotion. Paleobiology 25, 252-267.

Wilson, J.A., Sereno, P., 1998. Early evolution and higher level phylogeny of sauropod dinosaurs. Journal of Vertebrate Paleontology 18 (2), 1-68.

Zakharov, S.A., 1964. The Cenomanian dinosaur whose tracks were found in the Shirkent River valley. In: Reiman, V.M. (Ed.), Paleontology of Tadzhikistan. Akademia Nauk Tadzhik S.S.R. Press, Dushanbe, pp. 31-35 (In Russian with English summary). 